\section{A novel role for uroguanylin in the regulation of sodium balance}

\author{
Leonard R. Forte \\ Medical Research Service, Truman Memorial Veterans Administration Hospital and \\ Radiopharmaceutical Sciences Institute and Department of Medical Pharmacology and \\ Physiology, School of Medicine, University of Missouri, Columbia, Missouri, USA
}

\begin{abstract}
Uroguanylin is a peptide hormone that regulates sodium excretion by the kidney when excess $\mathrm{NaCl}$ is consumed. A new study demonstrates that mice deficient in uroguanylin have blunted urinary sodium excretion responses to oral sodium loads in addition to elevated blood pressure (see related article beginning on page 1244). A physiological role for uroguanylin is discussed, linking the intestine and kidney in an endocrine axis for the maintenance of sodium balance.
\end{abstract}

J. Clin. Invest. 112:1138-1141 (2003). doi:10.1172/JCI200320057.

Three different families of first messenger molecules are known to influence cellular function through mediation by the intracellular second messenger, cGMP. The regulatory molecules consist of guanylin, uroguanylin, $\mathrm{NO}$, and the atriopeptins. These hormone-like molecules bind selectively to and activate specific forms of receptor-guanylate cyclases (R-GCs) to produce and signal via cGMP within target cells. Guanylin and uroguanylin are the newest members of the greater family of cGMP-regulating agonists that have been identified. However, guanylin and uroguanylin also belong to a class of peptides that were actually the first recognized agonists for activation of an R-GC pathway. It was first reported in 1978 that a heat-stable (ST) peptide produced by Escherichia coli activated an intestinal R-GC, thus raising intracellular levels of cGMP, which then led to the stimulation of intestinal secretion and diarrhea $(1,2)$. With the power of hindsight, it can be seen that guanylin

\footnotetext{
Address correspondence to: Leonard R. Forte, University of Missouri, M-517 Medical Sciences Building, One Hospital Drive,

Columbia, Missouri 65212, USA.

Phone: (573) 814-6000; Fax: (573) 814-6551;

E-mail: lrf@missouri.edu.

Conflict of interest: The author has declared

that no conflict of interest exists.

Nonstandard abbreviations used:

receptor-guanylate cyclase (R-GC); heat stable

(ST); endothelium-derived relaxing factor

(EDRF); atrial natriuretic factor (ANF);

guanylyl cyclase C receptor (R-GC-C);

gastrointestinal (GI).
}

and/or uroguanylin should have been identified next as endogenous ST-like agonists for this orphan R-GC. If this had happened, guanylin and uroguanylin would be quite familiar to scientists at the present time. However, two events occurred at the beginning of the 1980s that shifted the emphasis of what was at that time a much smaller body of investigators working in the field of cGMP signaling. Endotheliumderived relaxing factor (EDRF) and atrial natriuretic factor (ANF) were discovered $(3,4)$. These factors spawned two large investigations that ultimately identified EDRF as NO and ANF as three different atriopeptins, while also elucidating that two different types of R-GCs are regulated by $\mathrm{NO}$ and atriopeptins. Much later, investigations into endogenous ST-like agonists for the intestinal R-GC pathway came back into focus when guanylin was isolated from rat intestine (5), an event which was soon followed by the isolation of uroguanylin from opossum urine (6). Guanylin and uroguanylin have striking similarities in structure and biological activity to the ST peptides of enteric bacteria (Figure 1). For example, these peptides are agonists of intestinal R-GC activation and also stimulate chloride secretion, indicating that ST peptides are simply molecular mimics of uroguanylin and guanylin. The intriguing findings of Lorenz and his colleagues reported in this issue of the JCI will help to raise new levels of interest in uroguanylin as a novel player in the complex physiological scheme that has evolved to regulate the urinary excretion of sodium chloride and thus to influence sodium balance and blood pressure in the body (7).

\section{Uroguanylin deficiency impairs sodium excretion}

Inactivation of uroguanylin genes in mice produces an animal model with an impaired capacity to excrete $\mathrm{NaCl}$ in urine when salt loads are administered orally (7). However, intravenous administration of $\mathrm{NaCl}$ to uroguan$y \mathrm{lin}^{-1-}$ mice elicits a natriuresis equivalent to that of wild-type animals. This novel finding seems surprising, yet had, in a sense, been predicted. The surprise comes in the authors' observations that inactivation of genes encoding guanylyl cyclase $\mathrm{C}$ receptor (R-GC-C) results in an animal that no longer exhibits intestinal secretion responses to these agonists, but appears to have no other physiological abnormalities or morphological changes $(8,9) . R$-GC-C $C^{-1-}$ animals have normal blood pressure. One explanation for the normal blood pressure and renal sodium excretion observed in the $R-G C-C^{-/}$mice is that regulation of renal sodium transport and thus urinary sodium excretion is not mediated by R-GC-C, but through another receptor for uroguanylin that has not been identified. Consistent with this concept are the findings of Carrithers et al. that intravenous treatment of $R$-GC-C $C^{-/}$mice with uroguanylin, guanylin, or ST peptides elicits saliuretic and diuretic responses that are quantitatively equal to the renal responses of $R$-GC- $C^{+/+}$animals (10). Clearly, the molecular identification of a second receptor for uroguanylin in the kidney is an important objective for those working in this area. Hints of such a receptor and signaling mechanism can be found in a study by Sindic et al., who report that a pertussis toxin-sensitive pathway is utilized in kidney cells for signal transduction initiated by uroguanylin (11). On the other hand, perhaps we should not be surprised by the report by Lorenz et al. (7) because Forte et al. had predicted that uroguanylin could serve in an endo- 


\section{GUANYLIN}

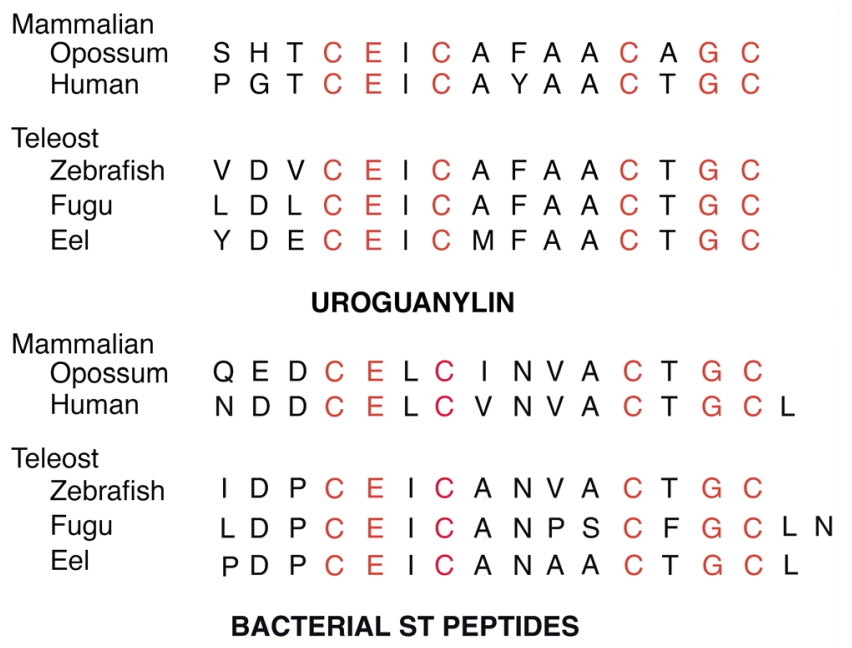

\section{V. cholerae ST I D C C E I C C N P A C F G C L N E. colist $\quad \mathrm{N} Y C \mathrm{C}$ E L C C N P A C T G C Y}

\section{Figure 1}

Primary structures of guanylin, uroguanylin, and bacterial ST peptides. Single letter abbreviations for the amino acids are used. The peptides are aligned using the conserved cysteine residues found in the three classes of peptides. Sequences for Zebrafish and Fugu peptides were derived from their respective genome sequencing projects, and those for eel peptides were taken from Yuge et al. (17).

crine axis connecting the gastrointestinal (GI) tract to the kidney for regulation of $\mathrm{NaCl}$ excretion (12). This hypothesis is based, at least in part, on observations made almost three decades ago that oral administration of $\mathrm{NaCl}$ induces a natriuresis that greatly exceeds the increase in urine sodium elicited by intravenous $\mathrm{NaCl}$ (13). An intestinal natriuretic factor was postulated to exist as one explanation for this finding. The factor is released from the GI system when $\mathrm{NaCl}$ is consumed and travels in the bloodstream to the kidney, where this substance could act as a natriuretic hormone. The current findings in uroguanylin ${ }^{-/}$animals reported by Lorenz et al. are consistent with the hypothesis that one physiological role for uroguanylin is regulating kidney function and helping to maintain body sodium balance (Figure 2). Such an intestine-kidney axis will likely be an oversimplification of the physiological mechanism that operates in vivo because uroguanylin is also produced in the kidney where it may act locally. Increases in dietary $\mathrm{NaCl}$ raise uroguanylin mRNA levels in the intestine and kidney, suggesting that both endocrine and paracrine/autocrine actions of uroguanylin could participate in tubular signaling mechanisms that govern renal sodium transport $(14,15)$.

\section{Uroguanylin and osmoregulation}

A fundamental question is: What specific physiological roles are played by uroguanylin versus guanylin in the body? It is quite clear that some selective process has been in effect for approximately the past 300 million years of vertebrate evolution to maintain the unique structures found in the active peptide forms of guanylin and uroguanylin (Figure 1). Uroguanylin structures are different when compared to guanylin within distantly related mammals such as the human and opossum or when comparisons are made between fish and mammals. The high degree of conservation of primary structures for these subclasses of peptide hormones implies that unique roles for guanylin and uroguanylin were established early during vertebrate evolution. It is likely that the basic mechanisms that evolved in fish are also conserved and function in mammalian species. A biological role for uroguanylin in the regulation of body sodium balance may be the mammalian counterpart to the possible contribution of uroguanylin to the processes controlling osmoregulation in euryhaline fish, which can adapt to living in either freshwater or seawater conditions. For example, uroguanylin mRNA levels are upregulated in the intestine and kidney when freshwateradapted eels are exposed to the considerably higher $\mathrm{NaCl}$ concentration of seawater $(16,17)$. This finding suggests that uroguanylin may function in fish to regulate body sodium levels in a fashion similar to the physiological role that Lorenz et al. (7) suggest for uroguanylin in the mouse, where the expression of uroguanylin mRNAs may also be under the influence of $\mathrm{NaCl}$ in the diet $(14,15)$. Might uroguanylin serve to regulate body sodium balance in mammals by some common regulatory mechanism(s) similar to those involved in the complicated physiology underlying osmoregulation in fish? If so, we can anticipate that this type of biological role for uroguanylin could be the main selective pressure that has contributed to conservation and maintenance of the primary structures of uroguanylin during vertebrate evolution.

\section{Properties of uroguanylin versus guanylin}

A specific feature of the structureactivity relationship for uroguanylin relates to specific residues within this molecule that contribute to its biological activity in the kidney. Studies using the T84 colon cell model may have provided some insights into some molecular features of the uroguanylin molecule that influence its biological activity. For example, the potency of uroguanylin remains high when the growth medium $\mathrm{pH}$ is reduced to an acidic condition, which in turn greatly reduces the potency of guanylin for activation of chloride secretion in T84 cells (18). The effects of $\mathrm{pH}$ appear to be manifest in the affinity of these peptides for interaction with R-GC-C. The unique acidic amino acids on the $\mathrm{N}$-terminus of uroguanylin contribute to the maintenance of high affinity and potency of uroguanylin under conditions of 


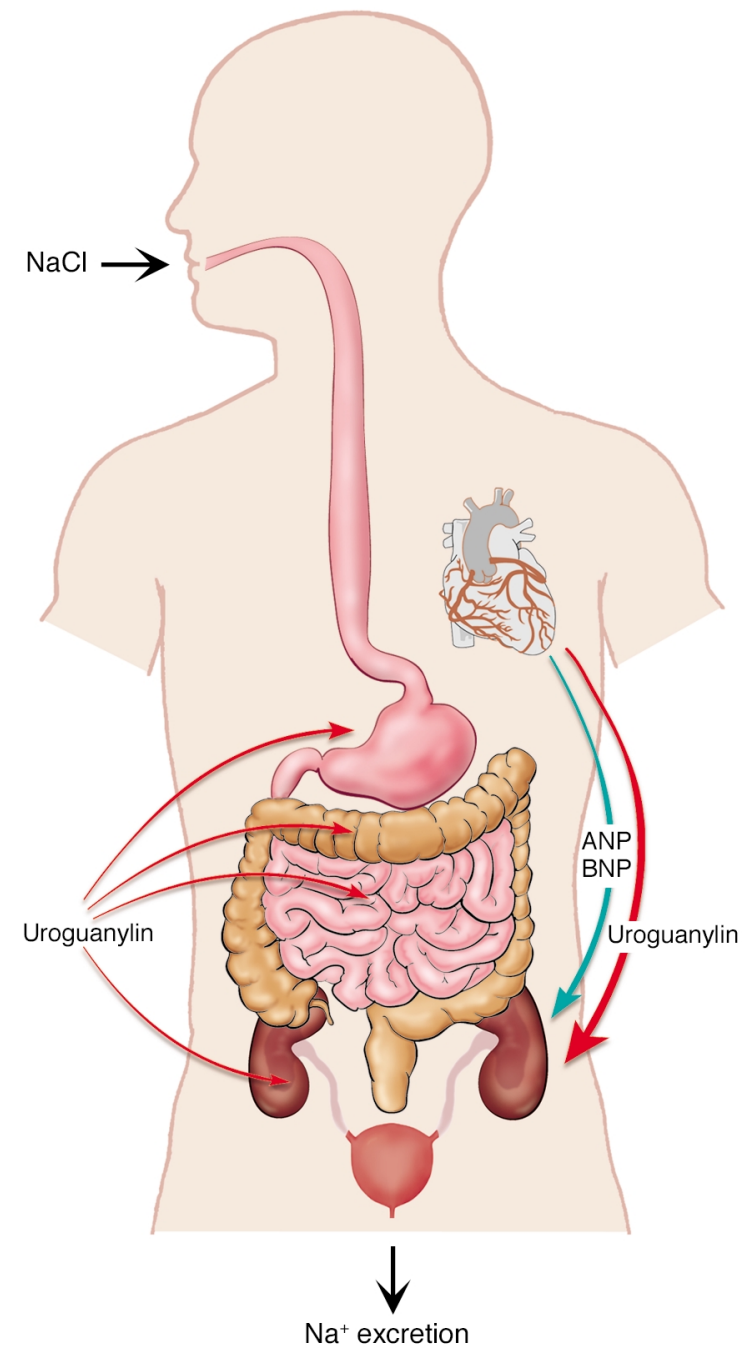

Figure 2

An endocrine axis linking together the $\mathrm{Gl}$ system and kidney via uroguanylin produced in the stomach and/or intestine and secreted into the circulatory system. The studies of Lorenz et al. (7) support the concept that uroguanylin may play a key physiological role serving as a natriuretic hormone produced by the $\mathrm{Gl}$ system and released into the circulatory system when excess $\mathrm{NaCl}$ is ingested. Atriopeptin-A (ANP), atriopeptin-B (BNP), and uroguanylin derived from the myocardium may, in some circumstances, also contribute to the natriuresis elicited by high salt loads in the postprandial state. Not shown in this model is the renal production of uroguanylin, guanylin, and atriopeptins, which could participate in intra-renal mechanisms that regulate tubular sodium transport and thus contribute to the saliuresis elicited by oral salt loads. A potential role for uroguanylin and/or guanylin in the CNS to influence the appetite for salt should also be considered in future studies. Figure modified with permission from the American Journal of Physiology (24).

acidic $\mathrm{pH}$, which elicits a marked reduction in the affinity of guanylin for this receptor. It should be pointed out that filtrate $\mathrm{pH}$ becomes acidic within the renal proximal tubules and that the currently identified receptors for uroguanylin are located primarily on the apical plasma membranes of renal tubular cells (19). Therefore, uroguanylin in the bloodstream may reach its receptors on tubular cells by by hydrolysis of the peptide bond $\mathrm{C}$-terminal to conserved tyrosine or phenylalanine residues found in guanylin peptides. Moreover, protease inhibitors enhance the biological activity of guanylin in the kidney (22). Proteases within renal tubules may degrade guanylin and prevent this peptide from activation of receptors in vivo. Thus, it is likely that the internal asparagine residue in uroguanylin contributes to the physiological activity of this peptide in the kidney. A third feature of uroguanylin peptides should be mentioned. Bacteria-derived ST peptides are closer mimics of uroguanylin bioactivity than that of guanylin. Figure 1 shows that uroguanylin and bacterial ST peptides share similarities in primary structure. The biological activity of uroguanylin in the ex vivo perfused kidney is more closely mimicked by E. coli ST than by guanylin (23). Caution may be advised when ST peptides are used instead of the specific physiological agonists, uroguanylin or guanylin, for activation of receptors in experimental settings. The findings of Lorenz et al. (7) clearly demonstrate that uroguanylin has specific regulatory actions in vivo that are not found in its close cousin, guanylin.

In closing, I would like to emphasize that guanylin and uroguanylin do not belong to the atriopeptin class of peptides that signal via activation of membrane R-GCs. Atriopeptins have no known ancestral relationship to guanylin and uroguanylin, other than being small peptides, although their cognate receptors are clearly derived from some ancestral form of membrane R-GC. Some confusion on this point appears from time to time in the literature. Is there something else that has not been recognized yet that connects together these two classes of cGMP-regulating agonists, other than using membrane R-GCs to signal through cGMP in target cells? Is it a mere coincidence that the atriopeptins and uroguanylin both participate in the physiological control of renal $\mathrm{NaCl}$ excretion and influence blood pressure? Could the appearance together of their genes on the same chromosome imply guilt by association? Perhaps some physiologically meaningful connection will be drawn from future 
studies that delve into such a conspiracy theory linking the evolution of uroguanylin and atriopeptins as regulators of sodium balance. It is clear that the seminal findings of Lorenz et al. (7) using the uroguanylin gene knockout mouse will be of major significance to investigators who are working to gain a better understanding of the regulatory mechanisms that govern body sodium balance and blood pressure. Uroguanylin now takes its place together with the other cGMP-regulating agonists, NO, and the atriopeptins in this physiological arena. Anniversaries are important; thus I wish to note that this article enters the literature on the 10th anniversary of our report of the isolation and identification of opossum uroguanylin (6). It is personally rewarding to observe a continued interest in this peptide hormone and its role in the body.

1. Hughes, J.M., Murad, F., Chang, B., and Guerrant, R.L. 1978. Role of cyclic GMP in the action of heat-stable enterotoxin of Escherichia coli. Nature. 271:755-756.

2. Field, M., Graf, L.H., Jr., Laird, W.J., and Smith, P.L. 1978. Heat-stable enterotoxin of Escherichia coli: in vitro effects on guanylate cyclase activity, cyclic GMP concentration, and ion transport in small intestine. Proc. Natl. Acad. Sci. U. S. A. 75:2800-2804.

3. Furchgott, R.F., and Zawadzki, J.V. 1980. The obligatory role of endothelial cells in the relaxation of arterial smooth muscle by acetylcholine. Nature. 288:373-376.

4. de Bold, A.J., Borenstein, H.B., Veress, A.T., and Sonnenberg, H. 1981. A rapid and potent natriuretic response to intravenous injection of atrial myocardial extract in rats. Life Sci. 28:89-94.

5. Currie, M.G., et al. 1992. Guanylin: an endogenous activator of intestinal guanylate cyclase. Proc. Natl. Acad. Sci. U. S. A. 89:947-951.

6. Hamra, F.K., et al. 1993. Uroguanylin: Structure and activity of a second endogenous peptide that stimulates intestinal guanylate cyclase. Proc. Natl. Acad. Sci. U. S. A. 90:10464-10468.

7. Lorenz,J.N., et al. 2003. Uroguanylin knockout mice have increased blood pressure and impaired natriuretic response to enteral $\mathrm{NaCl}$ load. J. Clin. Invest. 112:1244-1254. doi:10.1172/JCI200318743.

8. Schulz, S., Lopez, M.J., Kuhn, M., and Garbers, D.L. 1997. Disruption of the guanylyl cyclase-C gene leads to a paradoxical phenotype of viable but heat-stable enterotoxin-resistant mice. J. Clin. Invest. 100:1590-1595.

9. Mann, E.A., Jump, M.L., Wu, J., Yee, E., and Giannella, R.A. 1997. Mice lacking the guanylyl cyclase $\mathrm{C}$ receptor are resistant to $\mathrm{STa}$-induced intestinal secretion. Biochem. Biophys. Res. Commun. 239:463-466.

10. Carrithers, S.L., et al. 2003. Guanylin and uroguanylin induce natriuresis in mice lacking guanylyl cyclase-C. Kidney Int. In press.

11. Sindic, A., et al. 2002. Guanylin, uroguanylin, and heat-stable enterotoxin activate guanylate cyclase $\mathrm{C}$ and/or a pertussis toxin-sensitive $\mathrm{G}$ protein. J. Biol. Chem. 277:17758-17764.

12. Forte, L.R., Fan, X., and Hamra, F.K. 1996. Salt and water homeostasis: uroguanylin is a circulating peptide hormone with natriuretic activity. Am. J. Kidney Dis. 28:296-304.

13. Lennane, R.J., Peart, W.S., Carey, R.M., and Shaw, J.A. 1975. Comparison of natriuresis after oral and intravenous sodium loading in sodiumdepleted rabbits: evidence for a gastrointestinal or portal monitor of sodium intake. Clin. Sci. Mol. Med. 49:433-436.
14. Carrithers, S.L., et al. 2000. Guanylyl cyclase-C receptor mRNA distribution along the rat nephron. Regul. Pept. 95:65-74.

15. Potthast, R., et al. 2001. High salt intake increases uroguanylin expression in mouse kidney. Endocrinology. 142:3087-3097.

16. Comrie, M.M., Cutler, C.P., and Cramb, G. 2001 Cloning and expression of guanylin from the European eel (Anguilla anguilla). Biochem. Biophys. Res. Commun. 281:1078-1085.

17. Yuge, S., Inoue, K., Hyodo, S., and Takei, Y. 2003 A novel guanylin family (guanylin, uroguanylin, and renoguanylin) in eels. Possible osmoregulatory hormones in intestine and kidney. J. Biol. Chem. 278:22726-22733.

18. Hamra, F.K., Eber, S.L., Chin, D.T., Currie, M.G., and Forte, L.R. 1997. Regulation of intestinal uroguanylin/guanylin receptor-mediated responses by mucosal acidity. Proc. Natl. Acad. Sci. U. S. A. 94:2705-2710

19. Forte, L.R., Krause, W.J., and Freeman, R.H. 1989 Escherichia coli enterotoxin receptors: localization in opossum kidney, intestine and testis. Am. J. Physiol. 257:F874-F881.

20. Carpick, B.W., and Gariepy, J. 1993. The Escherichia coli heat-stable enterotoxin is a longlived superagonist of guanylin. Infect. Immun. 61:4710-4715

21. Hamra, F.K., et al. 1996. Prouroguanylin and proguanylin: purification from colon, structure, and modulation of bioactivity by proteases. Endocrinology. 137:257-265.

22. Santos-Neto, M.S., et al. 2003. Guanylin and its lysine-containing analogue in the isolated perfused rat kidney: Interaction with chymotrypsin inhibitor. Pharmacol. Toxicol. 92:114-120.

23. Fonteles, M.C., Greenberg, R.N., Monteiro, H.S.A., Currie, M.G., and Forte, L.R. 1998. Natriuretic and kaliuretic activities of guanylin and uroguanylin in the isolated perfused rat kidney. Am. J. Physiol. 275:F191-F197.

24. Forte, L.R., London, R.M., Freeman, R.H., and Krause, W.J. 2000. Guanylin peptides: renal actions mediated by cyclic GMP. Am. J. Physiol. Renal Physiol. 278:F180-F191. 